EDITORIAL

\title{
Interdisciplinary perspectives on place
}

\author{
There's no place like home. \\ - Dorothy Gale, in The Wizard of Oz
}

The genius loci of many places is beyond description. Beyond description in the sense that we are not able to linguistically express what it feels like to be in this place, or what it is that ultimately makes this place. For example, how could we describe the familiarity and the sense of belonging that we usually feel when we are at home, a place of origin. Home as a place can develop a very special identity and give us love, security, and comfort, but for some may evoke anxiety and fear instead, such as in cases of domestic violence. Only when we develop personal bounds to the flat, the building, the neighbourhood, or the city in which we live, does this feeling of home become accessible to us. Without the distinctive everyday routine, the habitus, and the familiarity, and perhaps also without the will to engage with the place, it never becomes a home. And this being elsewhere is the feeling Dorothy Gale has when she, in the film The Wizard of Oz, is whisked away to Munchkinland in the Land of Oz. She longs for home and wants to leave Munchkinland, but as we all know, this turns out not to be an easy task. Dorothy's famous and recitatively repeated saying "There's no place like home" embodies the previously described special aura of home to which she longs to return. Even if it remains unclear throughout the film whether Dorothy was only dreaming or really in the Land of $\mathrm{Oz}$, this suggests again that in many senses home is beyond compare.

The importance of the concept and term of place, which spans the wider frame of this Special Feature, manifests in the extent to which the word has become engrained in our language. In addition to its geographical meaning, the term place is also used in a figurative sense. New rules can be in place; an event may take place; and some unexpected strange behaviour can be out of place. Also, we say a place for everything and everything in its place when referring to keeping things organized by placing them where they should be; we wish to have a place in the sun; or even to go places. Many further usages of the term place exist, probably also because the concept of a place in the geographical sense is so diverse. The frequently chosen descriptions of place by means of the sense of a place [see, e.g., 5, 10,15], place attachment [see, e.g., 6, 13, 15], behavioural patterns and place ballets [see, e.g., 11, 12], place identity [see, e.g., 2,10], and many more seem only superficially appropriate in isolation. In full, however, we are able to grasp the holistic core and essence of a place only when combining these qualities in a description. The challenge to adequately represent 
a place or even to capture the understanding of places by means of information science methods is thus indeed a fairly complex endeavour [8].

The study of general place characteristics and corresponding information is increasingly becoming the focus of current research activities. For example, the Symposium on the Psychology of Places, which has been held for the first time in 2021, focused on how individuals perceive places and how social structures affect this [1]. Also in 2021, the keyword "place" has been added to the list of relevant topics in the call for papers of the International Conference on Spatial Information Theory (COSIT 2022) [3]. Finally, the International Symposium on Platial Information Science (PLATIAL'21) testifies that the scholarly exchange on the topic of platial information is able to attract and connect a growing number of researchers [cf., 9,16]. In addition to the frequent mention of place as a relevant research topic, a generally increased awareness of the complex nature of place is observed, especially with regards to elaborate geographical notions of place. It seems that the research focus in geographical information science and adjoining areas gradually shifts from POIs as locations with attributes towards places as significantly more complex geographical features.

Given the complexity of place and the magnitude of the endeavour to adequately understand place, it is not surprising that the study of place extends into many disciplines. Among them are geography, because places operate in geographical contexts; cognitive science and environmental psychology, when we systematically study the perception of places; and the wider social sciences and social psychology, because places are often socially constructed and socially lived. Further, information science and, in particular, geographical information science, when we study the nature of platial information at the interface to geography; the humanities and media studies, when we study the mediation of places in the various media and its effects; linguistics, when places are represented through speech acts; and philosophy, because in many ways places manifest one of the basic categories of concepts we use in everyday life. In the context of the systematic analysis of places, statistics takes a central role; and the visual mediation of platial characteristics is often discussed in the context of cartography. These examples demonstrate that place can and should be discussed in the context of different disciplines, and that in many cases a mono-disciplinary view would seem rather obstructive.

This Special Feature aims to contribute to shaping interdisciplinary perspectives on place. It forms part of the larger endeavour to address the topic of place in its full complexity and across disciplinary boundaries. The three articles published in the Special Feature reflect this understanding as they build bridges between different disciplines. The study reported by McKenzie and Mwenda [7], for instance, can be located at the interface of geography and geographical information science. It examines and compares the changing check-in behaviour of places in four major US cities during the COVID-19 pandemic. In doing so, the authors pay particular attention to regional and demographic differences. The study conducted by Tang, Acedo, and Painho [14], in contrast, relates to the disciplines of environmental and social psychology. This work examines how different kinds of place attachment depend on the length of residence and differ in particular between longterm residents and newcomers. In contrast to many other studies, the spatial component is not only seen as a categorization feature for different places-where is a place located and what is its size-but as a primary characteristic of place attachment. Finally, the paper by Kuhn et al. [4] explores the role of place-related question-answering systems and draws from the disciplines of information science and semantics. In particular, their work presented shows how possible questions can be derived from an ontology of spatial infor- 
mation and a classification of place facets, which can contribute to the further development of current applications in the age of Alexa, Cortana, and Siri.

The articles published in this Special Feature demonstrate once again how diverse places can be and how challenging it is to capture their essence with formal methods. However, this intractability is exactly what makes the topic of place so appealing in the context of geographical information sciences. Therefore, we hope that you, esteemed reader, will enjoy reading the articles as much as we have enjoyed reading them to then proceed with the topic of place even beyond.

Franz-Benjamin Mocnik University of Twente, the Netherlands

René Westerholt TU Dortmund University, Germany

\section{References}

[1] Calanchini, J., Essien, I., And Rohmann, A. Virtual symposium on the psychology of places. https://sites.google.com/view/psychology-of-places/overview, accessed on 3 December 2021.

[2] Dovey, K. Becoming places. Urbanism/architecture/identity/power. Routledge, London, UK, 2010.

[3] Ishikawa, T., FAbrikant, S. I., Winter, S., Bae, C., KATtenbeck, M., OKUnUKi, K., Sugimoto, M., AND TAKAHASHI, K. Call for papers for the 15th Conference on Spatial Information Theory (COSIT 2022). http://cosit2022.iniad.org, accessed on 3 December 2021.

[4] Kuhn, W., Hamzei, E., Tomko, M., Winter, S., And Li, H. The semantics of place-related questions. Journal of Spatial Information Science 23 (2021), 157-168. doi:10.5311/JOSIS.2021.23.161.

[5] KYLE, G., AND CHICK, G. The social construction of a sense of place. Leisure Sciences 29, 3 (2007), 209-225. doi:10.1080/01490400701257922.

[6] Low, S. M., AND Altman, I. Place attachment. A conceptual inquiry. In Place attachment, I. Altman and S. M. Low, Eds. Plenum, New York, NY, 1992, p. 1-12. doi:10.1007/978-1-4684-8753-4_1.

[7] MCKenZIE, G., AND Mwenda, K. M. Identifying regional variation in place visit behavior during a global pandemic. Journal of Spatial Information Science 23 (2021). doi:10.5311/JOSIS.2021.23.170.

[8] MocNIK, F.-B. Putting geographical information science in place - towards theories of platial information and platial information systems. Progress in Human Geography (in press).

[9] MocNiK, F.-B., AND WeSterHOlt, R., Eds. Interdisciplinary perspectives on place. Proceedings of the 2nd International Symposium on Platial Information Science (PLATIAL'19) (2020). doi:10.5281/zenodo.3628833. 
[10] Relph, E. Place and placelessness. Pion, London, UK, 1976.

[11] Seamon, D. A geography of the lifeworld. Croom Helm, London, UK, 1979. doi:10.4324/9781315715698.

[12] Seamon, D., And Nordin, C. Marketplace as place ballet. A Swedish example. Meddelanden frän Göteborgs Universitets Geografiska Institutioner. Serie B 67 (1980), 3541.

[13] Sмiтн, J. S., Ed. Explorations in place attachment. Routledge, London, UK, 2017. doi:10.4324/9781315189611.

[14] TANG, V., Acedo, A., And PAinho, M. Sense of place and the city: the case of non-native residents in Lisbon. Journal of Spatial Information Science 23 (2021), 125-155. doi:10.5311/JOSIS.2021.23.165.

[15] TUAN, Y.-F. Space and place. The perspective of experience. University of Minnesota Press, Minneapolis, MN, 1977.

[16] Westerholt, R., MocniK, F.-B., AND ZIPF, A., Eds. On the way to platial analysis: can geosocial media provide the necessary impetus? Proceedings of the 1st Workshop on Platial Analysis (PLATIAL'18) (2018). doi:10.5281/zenodo.1475269. 